\title{
IMPACT OF CROPPING PATTERN SHIFT ON LIVELIHOOD ASSETS OF THE FARMERS IN PUNJAB, PAKISTAN
}

\author{
aMuhammad Shahzad, aMuhammad Iftikhar, aBabar Shahbaz, bSyed A. Wajid \\ ${ }^{a}$ Institute of Agricultural Extension, Education and Rural Development, University of Agriculture Faisalabad, Pakistan. \\ ${ }^{b}$ Department of Agronomy, University of Agriculture Faisalabad, Pakistan.
}

\section{ARTICLE INF O}

\section{Article history}

Received: August 17, 2020

Revised: December 05, 2020

Accepted: December 23, 2020

\section{Keywords \\ Cotton \\ Economy \\ Sugar mills \\ Support price \\ Water shortage}

\section{A B S T R A C T}

Cotton area is shrinking in Pakistan as the farmers have started adopting sugarcane for many reasons such as increasing number of sugar mills in core cotton areas. This study aimed at exploring the impacts of this cropping pattern shift on livelihood of the farmers. This study was conducted in district Rahim Yar Khan, one of the cotton core area of Punjab province. Total 400 farmers participated in the study. A wellstructured interview schedule was administered in the field to conduct face to face interviews of the respondents. Descriptive statistics were applied to analyze the collected data through the Statistical Package for Social Sciences (SPSS) to form conclusions and to make recommendations. The results indicated that knowledge and skills about production of other crops, linkage with research and development institutions, livestock possession and cash income of the respondents increased in result of cropping pattern shift. Conversely, land fertility and water conservation were compromised after shifting from cotton to sugarcane crop in the study area. This study urges further exploration of merits and demerits of cropping pattern shifts followed by the impacts on agricultural system in the country. It is further recommended that the government should revamp the cotton policy for the coming year. For instance, announcing and sustaining a minimum support price of cotton for cotton growers could reinstate the growers to cotton cultivation.

\section{Corresponding Author: Muhammad Shahzad}

Email: 2009ag2806@uaf.edu.pk

(C) The Author(s) 2020.

\section{INTRODUCTION}

Pakistan stands fifth in terms of the cotton production and at third position for its consumption around the world. Pakistan's textile industry annually necessitates about 16 million cotton bales in order to meet its national and international orders, but the local production missed the target and stood under 10 million bales during 2018-19. Eventually, the industry was compelled to import the cotton from USA, China, Brazil, India and other countries in order to fulfill consumption needs (Hussain, 2019; Qureshi, 2019). There is no other opinion that textile manufacturing has a significant role in the fiscal growth of the country and provides employment to the millions of people associated with this sector (Ahmad et al., 2019; Government of Pakistan, 2018). Thus, it is primitive to substantiate the growth of cotton crop for the livelihoods of the farmers, industry and national economy. Cotton provides livelihoods to cotton growers, non-cotton growers, middlemen and also adds to the national economy and foreign exchange earnings of the country. Nearly, 60 percent exports of the country are heavily dependent on cotton.

The value of cotton is undeniable, but its production is vulnerable to many plights since 2014-15. For many 
factors related to production, protection, environment, marketing and policy the production of cotton is witnessed alarmingly low. The area under cotton cultivation is decreasing, total production is falling gradually down and overall productivity is expected to fall further. Ashraf et al. (2018) have forecasted that the area under cotton cultivation in the Punjab will increase, however the production will see a consistent fall each year. This drastic decline can potentially impact the livelihoods of farmers and the economy of country as well. Rehman et al. (2019) compared the cotton production in Pakistan with other cotton growing nations such as India and China and found a huge gap in production of cotton. The per acre cotton production in the Pakistan was considerably lower.

Pertinent to lower yield, high cost of production, poor returns and for many other unseen and political reasons farmers started to left cotton cultivation and adopt sugarcane as an alternate crop. The sugarcane is seen as less vulnerable to losses and farmers choose it in replacement to earn income for their livelihoods. Sugarcane crop, as compared to cotton was perceived as secure for its production and market price. Moreover, the provision of export subsidy to the sugar mills by the government elevated the confidence of farmers on sugarcane (Government of Pakistan, 2018; Rana, 2019). This rapid shifting of cotton towards water-loving sugarcane crop has resulted in the cropping pattern change over time. The growing of sugarcane crop that consumes double water than cotton in already waterscarce areas has threatened future farming in these areas (Farooq and Gheewala, 2019). Moreover, the cultivation of sugarcane also gives rise to moisture in the atmosphere which invites more pests to attack the cotton crop (Mahmood, 2017). In spite of these risks associated with the cultivation of sugarcane crop, the majority of the farmers keeps in view the economics of competing crops based on inputs-outputs prices paid and received. Farmers' choice for the adoption of a particular crop can also be determined through multiple factors such as human, social, physical, natural and financial resources (Government of Pakistan, 2019b). Therefore, the present study was conducted to examine the impact of cropping pattern shift on livelihood assets of the farmers. The literature on cropping pattern shift is scanty right now and these findings could be significant in bridging the research gap. The findings of this study can help out the concerned institutions to chalk out their future plans particularly for the cotton crop and its future prospects in the district Rahim Yar Khan, which is known for its cotton quality. Rahim Yar Khan has seen a sharp decline in cotton acreage during the past decade. Before 1992, there were only two sugar mills in Rahim Yar Khan, but now this number has been reached up to five and their crushing capacity had also been increased substantially, which has destroyed the cotton crop in this district (Afzal, 2017). This downward trend of cotton cultivation in district Rahim Yar Khan has negatively impacted the national production of the country. The area under the cotton crop is being occupied by sugarcane for many years largely because of the minimum support price on this crop and the presence of a large number of sugar mills in district Rahim Yar Khan (Khan, 2016; Bhutta, 2017; Ghumman, 2017). During the last 10 years from 2008-18, the area under cotton crop in district Rahim Yar Khan was reduced from 681 to 389 thousand acres showing a decline of $42 \%$ while during the same period the area under sugarcane crop was gone high from 234 to 477 thousand acres showing an increase of more than 50\% (Government of Pakistan, 2019a). This pity situation led authors to explore the shifting of cropping patterns and their impacts on farmers livelihoods.

\section{MATERIALS AND METHODS}

This study was conducted at the Institute of Agricultural Extension, Education and Rural Development, University of Agriculture, Faisalabad (UAF), Pakistan during the year 2018-19. We used cross-sectional survey design for this study. This design emphasizes data collection at one point in time from a sample selected to represent a larger population (Owens, 2002). There are total 36 districts in the Punjab, province of Pakistan. Punjab is denoted as bread and basket for the Pakistan specially because of its tremendous potential of agriculture. The Southern part of Punjab is famous for the cotton sector. The core areas include Rahim Yar Khan, Bahawalpur and Bahawalnagar. According to the report of (Pakistan Cotton Giners Association, 2018), Bahawalpur, Rahim Yar Khan and Bahawalnagar are first three leading cotton growing districts of the Punjab. Hence, taking this statistic into account, it was decided to select one district out of three through random sampling technique as study area. Thus, the Rahim Yar Khan was chosen as study area at random. Rahim Yar Khan is famous for its cotton quality and conducive environment for producing 
the best quality lint in the world (Haq, 2006; Ahmad et al., 2018). The population for the present study comprised of all those farmers in district Rahim Yar Khan who had been partially or completely shifted from cotton to the sugarcane crop. The study district consisted of four tehsils (sub-districts) viz Liaquatpur, Khanpur, Sadiqabad and Rahim Yar Khan. From each tehsil two union councils (UCs) were randomly selected and then two villages (total 16 villages) were randomly taken to select the sample size. In order to compile a list of shifted farmers, a benchmark survey was conducted in these 16 selected villages with the help of numberdar, field assistant, progressive farmers and some other known personalities of the study area. This list comprised of 4015 farmers who had been partially or completely shifted from cotton to sugarcane crop in all the selected villages from the four tehsils (sub-districts) viz Liaquatpur, Khanpur, Sadiqabad and Rahim Yar Khan. This master list served as a sampling frame for the study.

For viable sample size, the sample calculation formula developed by Yamane (1967) was used at a 95\% confidence interval and 5\% precision level. With the help of this table, a sample of 370 respondents was drawn while for the equal distribution and representation the sample size was extended to 400 respondents.

In order to ensure equal representation from all the 16 selected villages, 25 farmers were taken from each selected village for data collection, thus making a sum of 400 respondents. The data were collected through an interview schedule, mainly consisted of close-ended questions to ascertain the changes in livelihood assets of the respondents before and after shifting from cotton to sugarcane crop. The scale used to find out these changes was; $1=$ Very low, $2=$ Low, $3=$ Medium, $4=$ High, $5=$ Very high. The collected data were then analyzed by the Statistical Package for Social Sciences (SPSS) to draw conclusions and to make recommendations. Descriptive statistics such as mean, standard deviation was calculated. Moreover, t-test was applied for the comparative difference.

\section{RESULTS AND DISCUSSION}

\section{Demographical Attributes of the Respondents}

Demographics of the respondents are viewed as major determinants in the awareness and adoption of modern production practices (Hassan et al., 2005; Ali and Kumar,
2011; Jenkins et al., 2011; Thompson, 2012). Table 1 shows that 12.8 and $22 \%$ of respondents belonged to age categories of under 25 years and 26-35 years old respectively. Perhaps, these respondents were considerably young. More than one fourth $(28.2 \%)$ of respondents were aged between 46-55 years followed by $34.3 \%$ of respondents aged more than 55 years. Findings conclude that old age farmers were more in number as compared to young age farmers. The age could be the factors behind cropping pattern shift because old age farmers are perceived as less receptive to new technologies and are considered as having ability of not taking risk. Whereas, the young age farmers are viewed as having risk taking abilities. The development of young people's education plays a significant role in the livelihood of future generations through promoting productivity and efficiency in any future livelihood strategy (de Brauw and Rozelle, 2007; Yúnez-Naude and Edward Taylor, 2001).

Slightly greater than one fifth $(21.5 \%)$ of respondents were illiterate whereas $78.5 \%$ of respondents were literate. Among respondents, $33 \%$ had up to primary level of education. One fourth (25\%) of respondent had primary to middle level of education, $8.5 \%$ middle to matric and $12 \%$ had educational level of more than matriculation. The findings indicate that educational level was just an ordinary in the study area as hardly $12 \%$ had more than 10 years of schooling (matriculation). Education is augmented as key tool in order to understand emerging needs of the farming. The ordinary educational level could have urged farmers to shift their cropping patterns.

Close to half $(49.3 \%)$ of the respondents were owner of their agricultural lands and $33.3 \%$ of respondents were owner-cum-tenants. There were $17.5 \%$ tenants in the total sample. The great numbers of owner-cum-tenants is a notion that farmers had great affiliation with the farming. This is further accentuated that $55.3 \%$ of farmers had reliance on agriculture (crop farming + livestock farming) in order to generate income. Of the total respondents, $27.3 \%$ had dependency on crop farming for the income.

Findings indicate that $43 \%$ of farmers had over 20 years of experience of cotton cultivation. Only $6.3 \%$ of respondents had less than 5 years of experience. Perhaps these were the young farmers who have recently started farming. Half of respondents (50\%) shifted their cropping pattern during last 5 years where 
as $14.5 \%$ of respondents had partially switched to sugarcane 15 years ago. This is indeed an alarming situation that experienced cotton growers have left cotton cultivation and the recent 5-6 years are considered as critical. This situation concludes that this shifting may not be optional but the circumstance and dubious scenario of cotton compelled farmers to shift their cropping patterns in the core areas.

Table 1. Distribution of respondents according to their age.

\begin{tabular}{|c|c|c|}
\hline Demographic attributes & Frequency & Percentage \\
\hline \multicolumn{3}{|c|}{ Age } \\
\hline Up to 25 years & 51 & 12.8 \\
\hline $26-35$ years & 88 & 22.0 \\
\hline $36-45$ years & 11 & 2.8 \\
\hline $46-55$ years & 113 & 28.2 \\
\hline Above 55 years & 137 & 34.3 \\
\hline \multicolumn{3}{|c|}{ Education Level } \\
\hline Illiterate & 86 & 21.5 \\
\hline Up to primary & 132 & 33.0 \\
\hline Primary to middle & 100 & 25.0 \\
\hline Middle to matric & 34 & 8.5 \\
\hline Above matric & 48 & 12.0 \\
\hline \multicolumn{3}{|c|}{ Tenancy Status } \\
\hline Owner & 197 & 49.3 \\
\hline Tenant & 70 & 17.5 \\
\hline Owner-cum tenant & 133 & 33.3 \\
\hline \multicolumn{3}{|c|}{ Sources of Income } \\
\hline Farming & 109 & 27.3 \\
\hline Farming + livestock & 221 & 55.3 \\
\hline Farming + non-farming & 70 & 17.5 \\
\hline \multicolumn{3}{|c|}{ Cotton Cultivation Experience } \\
\hline Less than 5 years & 25 & 6.3 \\
\hline $6-10$ years & 51 & 12.8 \\
\hline $11-15$ years & 49 & 12.3 \\
\hline $16-20$ & 103 & 25.8 \\
\hline More than 20 years & 172 & 43.0 \\
\hline \multicolumn{3}{|c|}{ Cotton Shifting Period } \\
\hline Less than 5 years & 200 & 50.0 \\
\hline $6-10$ years & 98 & 24.5 \\
\hline $11-15$ years & 44 & 11.0 \\
\hline More than 15 years & 58 & 14.5 \\
\hline
\end{tabular}

Table 2. Impact of cropping pattern shift on human assets.

\begin{tabular}{|c|c|c|c|c|c|c|}
\hline Human Assets & & Mean & S.D. & Std. Error Mean & T-value & P-value \\
\hline \multirow[t]{2}{*}{ Knowledge about the production of other crops } & Before & 3.29 & 1.46 & .073 & \multirow{2}{*}{-11.84} & \multirow{2}{*}{$.000^{* *}$} \\
\hline & After & 4.19 & 1.08 & .054 & & \\
\hline \multirow{2}{*}{ Skills about production techniques of other crops } & Before & 3.27 & 1.49 & .075 & \multirow{2}{*}{-14.55} & \multirow{2}{*}{$.000^{* *}$} \\
\hline & After & 4.35 & .98 & .049 & & \\
\hline \multirow[t]{2}{*}{ Family health } & Before & 3.57 & 1.49 & .075 & \multirow{2}{*}{-3.87} & \multirow{2}{*}{$.000^{* *}$} \\
\hline & After & 3.88 & 1.36 & .068 & & \\
\hline \multirow[t]{2}{*}{ Health condition of the person working in the field } & Before & 3.12 & 1.51 & .075 & \multirow{2}{*}{-12.39} & \multirow{2}{*}{$.000^{* *}$} \\
\hline & After & 4.09 & 1.16 & .058 & & \\
\hline \multirow[t]{2}{*}{$\overline{\text { Working capacity }}$} & Before & 3.42 & 1.51 & .075 & \multirow{2}{*}{-7.00} & \multirow{2}{*}{$.000^{* *}$} \\
\hline & After & 3.99 & 1.23 & .061 & & \\
\hline
\end{tabular}


T-statistics ( $\mathrm{t}$-value $=11.84$ ) show a significant difference of knowledge about production of other crops between before $(3.29 \pm 1.46)$ and after $(4.19 \pm 1.08)$ in favor of after shifting from cotton to sugarcane crop (Table 2). This implies that farmers' knowledge regarding production of other crops was significantly increased after moving towards sugarcane. Similarly, T-statistics (t-value $=14.55)$ showed a statistically significant difference $(\mathrm{P}<0.05)$ of skills regarding production techniques of other crops between before $(3.27 \pm 1.49)$ and after (4.35 \pm .98) in favor of after shifting from cotton to sugarcane crop. There was a statistically significant difference ( $\mathrm{t}$-value $=3.87$ ) difference in family health between before $(3.57 \pm 1.49)$ and after $(3.88 \pm 1.36)$ in favor of after shifting from cotton to sugarcane crop. The possible reason could be an increase in income by adopting sugarcane and farmers were able to spend thus earning on their families and their health. T-statistics ( $t$ value $=12.39$ ) showed a significant difference in the health condition of the person working in the field between before $(3.12 \pm 1.51)$ and after $(4.09 \pm 1.16)$ in favor of after shifting from cotton to sugarcane crop. The health condition of person working in the field was improved after shifting towards sugarcane because cotton crop needed excessive number of pesticides from sowing to harvesting whereas the sugarcane crop is considerably a smaller number of pesticides spray. Tstatistics (t-value=7.00) confirms that the working capacity of the farmers increased by shifting their cropping patterns as the significant difference in working capacity between before $(3.42 \pm 1.51)$ and after $(3.99 \pm 1.23)$ is witnessed $(\mathrm{P}<0.05)$ in favor of after shifting from cotton to sugarcane crop.

Table 2 concludes that there was an improvement in all the human assets of the farmers after cropping pattern shift. These results are in line to those of (Pervez et al., 2017) as they found a significant impact of cropping pattern change on human capital.

Table 3. Impact of cropping pattern shift on social assets.

\begin{tabular}{|c|c|c|c|c|c|c|}
\hline Social Assets & & Mean & S.D. & Std. Error Mean & T-value & P-value \\
\hline \multirow[t]{2}{*}{ Interaction with fellow farmers } & Before & 4.34 & 1.02 & .051 & \multirow{2}{*}{9.81} & \multirow{2}{*}{$.000^{* *}$} \\
\hline & After & 3.67 & 1.41 & .071 & & \\
\hline \multirow[t]{2}{*}{ Interaction with farmers outside the village } & Before & 3.60 & 1.44 & .072 & \multirow{2}{*}{-.81} & \multirow{2}{*}{$.420^{\mathrm{NS}}$} \\
\hline & After & 3.66 & 1.42 & .071 & & \\
\hline \multirow{2}{*}{$\begin{array}{l}\text { Linkage with research and development } \\
\text { institutions }\end{array}$} & Before & 3.22 & 1.49 & .074 & \multirow{2}{*}{-15.13} & \multirow{2}{*}{$.000^{* *}$} \\
\hline & After & 4.33 & 1.04 & .052 & & \\
\hline \multirow[t]{2}{*}{ Interaction with Extension Field Staff (EFS) } & Before & 4.27 & 1.08 & .054 & \multirow{2}{*}{14.53} & \multirow{2}{*}{$.000^{* *}$} \\
\hline & After & 3.27 & 1.48 & .074 & & \\
\hline \multirow[t]{2}{*}{ Involvement in social activities } & Before & 3.45 & 1.49 & .075 & \multirow{2}{*}{-7.85} & \multirow{2}{*}{$.000^{* *}$} \\
\hline & After & 4.07 & 1.29 & .065 & & \\
\hline \multirow[t]{2}{*}{ Interaction with sugarcane mills } & Before & 2.93 & 1.54 & .077 & \multirow{2}{*}{-18.69} & \multirow{2}{*}{$.000^{* *}$} \\
\hline & After & 4.26 & 1.02 & .051 & & \\
\hline \multirow[t]{2}{*}{ Interaction with other organizations } & Before & 3.30 & 1.48 & .074 & \multirow{2}{*}{-9.62} & \multirow{2}{*}{$.000^{* *}$} \\
\hline & After & 4.09 & 1.23 & .061 & & \\
\hline \multirow[t]{2}{*}{ Networking linkages } & Before & 3.62 & 1.50 & .075 & \multirow{2}{*}{-1.86} & \multirow{2}{*}{$.063^{\mathrm{NS}}$} \\
\hline & After & 3.75 & 1.41 & .071 & & \\
\hline \multirow[t]{2}{*}{ Funds assistance } & Before & 3.38 & 1.52 & .076 & \multirow{2}{*}{-4.14} & \multirow{2}{*}{$.000^{* *}$} \\
\hline & After & 3.76 & 1.41 & .071 & & \\
\hline
\end{tabular}

Table 3 indicates that there was a significant difference $(\mathrm{P}<0.05)$ (t-value $=9.31)$ in interaction with fellow farmers before $(4.34 \pm 1.02)$ and after $(3.67 \pm 1.41)$ cropping pattern shift. Farmers improved their interaction with their fellow farmers after shifting from cotton to sugarcane crop, might be in order to access information regarding the recommended production techniques of the sugarcane. $\mathrm{T}$-statistics ( $\mathrm{t}$-value $=0.81$ ) showed a non-significant difference in interaction with farmers outside the village. This implies the respondents had almost same interaction with farmers outside the village before and after shifting from cotton to sugarcane 
crop. Table 3 further shows that T-statistics (t-value $=15.13$ ) indicated a significant difference in linkage with research and development institutions between before $(3.22 \pm 1.49)$ and after $(4.33 \pm 1.04)$ in favor of after shifting from cotton to sugarcane crop. Perhaps the linkage with research and development institutions improved for information seeking and accessing technical guidance from the experts. DFID (2001) stated that social resources are the basis on which most of the people are dependent for their livelihoods. Likewise, Saravanan (2010) also stated that households with higher social assets such as participation in social networks, groups, and institutions are more capable for the adoption of various livelihood strategies.

Table 4. Impact of cropping pattern shift on natural and physical assets.

\begin{tabular}{|c|c|c|c|c|c|c|}
\hline Natural and Physical Assets & & Mean & S.D. & Std. Error Mean & T-value & P-value \\
\hline \multirow[t]{2}{*}{ Soil fertility } & Before & 4.46 & .836 & .042 & \multirow{2}{*}{20.203} & \multirow{2}{*}{$.000^{* *}$} \\
\hline & After & 3.21 & 1.510 & .075 & & \\
\hline \multirow[t]{2}{*}{ Area under cultivation } & Before & 3.77 & 1.365 & .068 & \multirow{2}{*}{-2.630} & \multirow{2}{*}{$.009^{* *}$} \\
\hline & After & 3.96 & 1.258 & .063 & & \\
\hline \multirow[t]{2}{*}{ Water conservation } & Before & 4.12 & 1.171 & .059 & \multirow{2}{*}{13.538} & \multirow{2}{*}{$.000^{* *}$} \\
\hline & After & 3.19 & 1.475 & .074 & & \\
\hline \multirow[t]{2}{*}{ Access to markets } & Before & 3.60 & 1.444 & .072 & \multirow{2}{*}{-2.997} & \multirow{2}{*}{$.003^{* *}$} \\
\hline & After & 3.84 & 1.327 & .066 & & \\
\hline \multirow[t]{2}{*}{ Livestock } & Before & 3.33 & 1.432 & .072 & \multirow{2}{*}{-14.901} & \multirow{2}{*}{$.000^{* *}$} \\
\hline & After & 4.39 & 0.935 & .047 & & \\
\hline \multirow[t]{2}{*}{ Housing condition } & Before & 3.15 & 1.522 & .076 & \multirow{2}{*}{-15.729} & \multirow{2}{*}{$.000^{* *}$} \\
\hline & After & 4.33 & 1.006 & .050 & & \\
\hline \multirow[t]{2}{*}{ Agricultural machinery } & Before & 4.05 & 1.196 & .060 & \multirow{2}{*}{9.582} & \multirow{2}{*}{$.000^{* *}$} \\
\hline & After & 3.36 & 1.445 & .072 & & \\
\hline \multirow[t]{2}{*}{ Transportation means } & Before & 3.81 & 1.374 & .069 & \multirow{2}{*}{-3.829} & \multirow{2}{*}{$.000^{* *}$} \\
\hline & After & 4.11 & 1.210 & .061 & & \\
\hline \multirow[t]{2}{*}{ Availability of labor } & Before & 3.66 & 1.419 & .071 & \multirow{2}{*}{-9.337} & \multirow{2}{*}{$.000^{* *}$} \\
\hline & After & 4.34 & 0.986 & .049 & & \\
\hline \multirow{2}{*}{$\begin{array}{l}\text { Household amenities like T.V. and other } \\
\text { electronic equipment }\end{array}$} & Before & 3.84 & 1.312 & .066 & \multirow{2}{*}{-3.119} & \multirow{2}{*}{$.002^{* *}$} \\
\hline & After & 4.06 & 1.249 & .062 & & \\
\hline
\end{tabular}

According to the Table 4, T-statistics ( $\mathrm{t}$-value $=20.203$ ) showed a significant difference in soil fertility before (4.46 \pm 0.83$)$ and after $(3.21 \pm 1.51)$ cropping pattern shift. Farmers argued that sugarcane cultivation had an impact on soil fertility. Being a yearly crop and water intensive crop, it had degraded the fertility level in some areas and in result cost of fertilizer could jump to higher. Chi et al. (2016) had the same conclusion that prolonged sugarcane cultivation in Brazil had detrimental effects on fertility of soil.

T-statistics (t-value $=2.630$ ) also show a significant difference in the area under cultivation between before $(3.77 \pm 1.36)$ and after $(3.96 \pm 1.25)$ in favor of after moving away from cotton. This indicates there was a minor change in total cultivated area of the farmers despite of the cropping pattern shift. T-statistics ( $t$-value
$=13.538$ ) explored a statistically significant difference in water conservation between before $(4.12 \pm 1.71)$ and after $(3.19 \pm 1.47)$ of cropping pattern shift. It was observed that water conservation was better in cotton crop as compared to sugarcane crop, which considerably requires high amount of water to mature. Farooq et al. (2019) had reported that sugarcane crop is water intensive and the need is to work on water use efficiency particularly in Pakistan where water availability is decreasing gradually. There was a statistically significant $(\mathrm{P}<0.05)$ difference ( $\mathrm{t}$-value $=2.997)$ regarding access to markets before $(3.60 \pm 1.44)$ and after $(3.84 \pm 1.32)$ cropping pattern shift. Due to availability of sugar mills in the study areas, the access of farmers to sugarcane market has increased. This was the major persuasion that led farmers towards shifting their 
cropping pattern. On other hand, the market of cotton in the area is uncertain and often growers face a loss. The certainty of the market and support price were the key enablers for the farmers to adopt sugarcane. (Khan and Jamil, 2004) cited the increase in domestic sugar mills a profound reason to bring increase in area and production of the sugarcane. T-statistics ( $t$-value $=14.901$ ) show a significant difference in livestock between before $(3.33 \pm 1.43)$ and after $(4.39 \pm 0.93)$ in favor of after shifting from cotton to sugarcane. The Table 4 concludes that growing of sugarcane crop had created long-lasting problems for the natural resources such as water and soil. However, the sugarcane crop right now was being observed as better than cotton for its established market and certain support price. OECD (2015) has reported that developing countries are particularly vulnerable to negligence and loss of natural capitals, while their limited income and institutional capacity undermine their ability to adapt to environmental risks. Similarly, Chambers and G. Conway (1992) stated that the livelihood of millions of rural households worldwide is closely related to the environment; therefore, a livelihood must not threaten the natural resource base at any cost. This is the notion that could happen in the future if sugarcane crop is remained operational in the study area.

Table 5. Impact of cropping pattern shift on financial assets.

\begin{tabular}{|c|c|c|c|c|c|c|}
\hline Financial assets & & Mean & S.D. & Std. Error Mean & T-value & P-value \\
\hline \multirow[t]{2}{*}{ Cash income } & Before & 3.38 & 1.511 & .076 & \multirow{2}{*}{-11.834} & \multirow{2}{*}{$.000^{* *}$} \\
\hline & After & 4.25 & 1.097 & .055 & & \\
\hline \multirow[t]{2}{*}{ Credit availability } & Before & 3.27 & 1.488 & .074 & \multirow{2}{*}{-8.107} & \multirow{2}{*}{$.000^{* *}$} \\
\hline & After & 3.82 & 1.364 & .068 & & \\
\hline \multirow[t]{2}{*}{ Off-farm income } & Before & 3.24 & 1.472 & .074 & \multirow{2}{*}{-13.608} & \multirow{2}{*}{$.000^{* *}$} \\
\hline & After & 4.16 & 1.098 & .055 & & \\
\hline \multirow[t]{2}{*}{ Savings } & Before & 3.33 & 1.468 & .073 & \multirow{2}{*}{-11.675} & \multirow{2}{*}{$.000^{* *}$} \\
\hline & After & 4.17 & 1.139 & .057 & & \\
\hline
\end{tabular}

Table 5 indicates a statistically significant difference ( $\mathrm{t}$ value $=11.834)$ in cash income before $(3.38 \pm 1.51)$ and after $(4.25 \pm 1.097)$ cropping pattern shift $(\mathrm{P}<0.05)$. This implies that sugarcane cultivation earned more income to the farmers as compared to income earned from cotton cultivation. High production, marketing and certain support prices were the possible reasons for this increase in income. $T$-statistics ( $\mathrm{t}$-value $=8.107$ ) showed a significant change in credit availability before $(3.27 \pm 1.48)$ and after $(3.82 \pm 1.364)$ cropping pattern shift. $\mathrm{T}$-statistics ( $\mathrm{t}$-value $=13.608)$ showed a significant difference in off-farm income before $(3.24 \pm 1.47)$ and after $(4.16 \pm 1.09)$ shifting the cropping pattern. This increase in non-farm income was mainly resulted from the minimized use of family labor in sugarcane crop. Cotton is usually labor-intensive crop. There was a significant difference in savings before $(3.33 \pm 1.46)$ and after (4.17 \pm 1.13$)$ cropping shift in favor of after shifting from cotton to sugarcane. The savings of the farmers were improved because they have had to spend less money for labor, pesticides and fertilizers in sugarcane as compared to the cotton crop. It is evident from the above results that adoption of new cropping pattern was profitable to the farm families. An increase in financial assets helps the farmers find out new livelihood strategies such as businesses and self-employment (Dehghani et al., 2018). They also explained that farmers prefer to save their financial assets by buying physical assets such as livestock and production assets (land, farm implements, etc.).

\section{CONCLUSIONS AND RECOMMENDATIONS}

This study explored the impact of cropping pattern shift on livelihoods of the farmers who have partially or fully shifted to sugarcane cultivation. This study concludes that cropping pattern shift was exclusively in benefit of the farmers. The most of the livelihood assets such as financial and physical increased significantly. By adopting the sugarcane, farmers had more savings, spare labour, opportunity to work off-farm and curtail cost of production. The availability of sugar mills in the study area and certain of market price gave sugarcane farmers an edge over cotton crop. From farmers perspective cropping pattern shift was beneficial and seems to last 
longer. This study explored some worries as well associated with the sugarcane cultivation in cotton core area. For instance, the cultivation of sugarcane crop has started to endanger the natural resources such as soil and water. Sugarcane, being water intensive and yearly crop, the fertility level of soil was impacted otherwise whereas the water conservation was compromised. In case of cotton, water conservation was better. Cotton is source of raw material for industry; thus, its production is indeed key for the country. This study urges to revamp the cotton policy in the country. In order to sustain the natural resources, there is need to discourage cropping pattern shift in the cotton core areas. The need of the hour is to establish a structure marketing for the cotton growers and announcement of certain support price which could possibly attract farmers back to the cotton crop.

\section{REFERENCES}

Afzal, A. 2017. Case of sugar mills in cotton growing areas.

Ahmad, A., M. Iftikhar, B. Shahbaz, C. O. Igodan, K. Lechman and G. A. Khan. 2019. Assessment of skills gap among intermediaries of cotton supply chain in Punjab, Pakistan. International Journal of Agricultural Extension, 6: 186-91.

Ahmad, A., M. Iftikhar, B. Shahbaz and G. A. Khan. 2018. Marketing chain of cotton in punjab, pakistan: Skills gap analysis of farmers. Journal of Agricultural Research, 56.

Ali, J. and S. Kumar. 2011. Information and communication technologies (ICTs) and farmers' decision-making across the agricultural supply chain. International Journal of Information Management, 31: 149-59.

Ashraf, S., A. H. Sangi, Z. Y. Hassan and M. Luqman. 2018. Future of Cotton Sector in Pakistan: A 2025 Outlook. Pakistan Journal of Agricultural Research, 31.

Bhutta, Z. 2017. Govt. to frame policy to restrict spread of sugar mills in cotton zone.

Chambers, R. and G. Conway. 1992. Sustainable rural livelihoods: practical concepts for the 21st century. Institute of Development Studies (UK).

de Brauw, A. and S. Rozelle. 2007. Reconciling the Returns to Education in Off-Farm Wage Employment in Rural China. Review of Development Economics, 12: 57-71.
Dehghani, P., Milad, A. A. Barati, H. Azadi and J. Scheffran. 2018. Revealing the role of livelihood assets in livelihood strategies: Towards enhancing conservation and livelihood development in the Hara Biosphere Reserve, Iran. Ecological Indicators, 94: 336-47.

DFID. 2001. Changing thinking: sustainable livelihoods. Poverty Elimination: The role of Economic and Social Research. Economic and Social Research Unit (ESCOR),Department for International Development (DFID). London.

Farooq, N. and S. H. Gheewala. 2019. Water use and deprivation potential for sugarcane cultivation in Pakistan. Journal of Sustainable Energy \& Environment 10: 33-93.

Ghumman, M. 2017. Cotton growing areas shrink: Govt. to revisit sugar policy

Government of Pakistan. 2018. Economic Survey of Pakistan, Federal Bureau of Statistics. Islamabad, Pakistan

Economic survey of Pakistan. 2019a. In Finance Devision (Ed.),Government of Pakistan. Islamabad, Pakistan.

PCCC. 2019b. Pakistan Central Cotton Committee (PCCC). Ministry of National Food Security and Research. Monthly Cotton Review. Islamabad, Pakistan.

Haq, M. I. 2006. Changing cropping pattern posing threat.

Hassan, M., A. Majeed and I. Rehman. 2005. Correlation of demographic characters of the respondents with usefulness and effectiveness of technical trainings as organized by PRSP in district Muzaffargarh.

Hussain, K. 2019. Pakistan's reliance on imported cotton on the rise

Jenkins, A., M. Velandia, D. M. Lambert, R. K. Roberts, J. A. Larson, B. C. English and S. W. Martin. 2011. Factors Influencing the Selection of Precision Farming Information Sources by Cotton Producers. Agricultural and Resource Economics Review, 40: 307-20.

Khan, A. F. 2016. Punjab's diminishing crop.

Khan, I. and M. Jamil. 2004. Sugar crops and sugar policy of Pakistan. Sci. Vision, 9: 1-8.

Mahmood, A. 2017. Sugar mills' relocation divides farmers in Punjab

OECD. 2015. Global and local environmental 
sustainability, development and growth.

Owens, L. K. 2002. Introduction to survey research design SRL fall 2002 seminar series. pp. 78-105.

Pakistan Cotton Giners Association. 2018. Arrival Report 01 May 2018.

Pervez, A., S. Rahman and A. Al-Amin. 2017. Change in cropping patterns and its impacts on farmers'livelihood in some selected areas of mymensingh district. Bangladesh Journal of Agricultural Economics, 36: 1-13.

Qureshi, S. 2019. Cotton connection.

Rana, P. I. 2019. Cotton production is falling as sowing area shrinks

Rehman, A., L. Jingdong, A. A. Chandio, I. Hussain, S. A. Wagan and Q. U. A. Memon. 2019. Economic perspectives of cotton crop in Pakistan: A time series analysis (1970-2015) (Part 1). Journal of the Saudi Society of Agricultural Sciences, 18: 4954.

Saravanan, R. 2010. ICTs for agricultural extension: Global experiments, innovations and experiences New india publishing.

Thompson, N. M. 2012. Two studies evaluating input use in soybean and cotton production, University of Tennessee.

Yúnez-Naude, A. and J. Edward Taylor. 2001. The Determinants of Nonfarm Activities and Incomes of Rural Households in Mexico, with Emphasis on Education. World Development, 29: 561-72.

Publisher's note: EScience Press remains neutral with regard to jurisdictional claims in published maps and institutional affiliations.

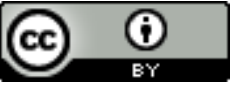

Open Access This article is licensed under a Creative Commons Attribution 4.0 International License, which permits use, sharing, adaptation, distribution and reproduction in any medium or format, as long as you give appropriate credit to the original author(s) and the source, provide a link to the Creative Commons license and indicate if changes were made. The images or other third-party material in this article are included in the article's Creative Commons license, unless indicated otherwise in a credit line to the material. If material is not included in the article's Creative Commons license and your intended use is not permitted by statutory regulation or exceeds the permitted use, you will need to obtain permission directly from the copyright holder. To view a copy of this license, visit http://creativecommons.org/licenses/by/4.0/. 